\title{
A Study on Training Factors and Its Impact on Training Effectiveness in Kedah State Development Corporation, Kedah, Malaysia
}

\author{
Dr. Vimala Sanjeevkumar \\ Associate Professor-College of Business, University of Utara Malaysia, Sintok, Kedah \\ Email: virmala@uum.edu.my
}

Ms. Hu Yanan

Masters in Human Resource Management, University of Utara Malaysia, Sintok, Kedah

Email: missing122@hotmail.com

Accepted: November 2, 2011 Published: December 4, 2011

doi:10.5296/ijhrs.v1i2.1130

URL: http://dx.doi.org/10.5296/ijhrs.v1i2.1130

\begin{abstract}
In Malaysia so many enterprise implement various training program to enhance their employees by working performance. But as overall view, the training environment still exist shortages in enterprise today, for instance, lack of knowledge of training, resources, trainer etc.. Employee training has been a matter of concern and attention by many business fields nowadays. Organizations realize that employee training is an essential element to increase efficiency of job performance and keep their business running, as competition are getting more intense. Training is the process of providing employees with specific skills or helping them correct deficiencies in their performance (David, 2010).This study, combining theoretical and empirical research, trying to find factors that affect employee training and its impact in acting human resource practices thereby laying the theoretical foundation for the future research about survey on the employee training, also provide a good reference. Therefore, the problem addressed in this study is examine the factors affect training (types of training, training environment, work environment and employees' personal characteristics) and training effectiveness on human resource practices in Kedah State Development Corporation (KSDC) which is the parent company under BDB Company. This
\end{abstract}


research also determine the main factors which influence employee training on human resource practices. Management is committed to human resource development as well as its social responsibilities through various programs. Training and development programs are offered by the KSDC Company that training program also adapted to the latest technological advances.

Key words: Job performance, Skills, Technological advances, Training, Work environment

\section{Introduction}

Employee training has been a matter of concern and attention by any business field nowadays. Organizations realize that employee training is an essential element to increase efficiency of job performance and keep their business running, as competition are getting more intense. Training is the process of providing employees with specific skills or helping them correct deficiencies in their performance (David, 2010). For example, new equipment may require workers to learn new ways of doing the job or a worker may have a deficient understanding of a work process. In both sides, training can be used to correct the skill deficit. Training is focus on the current job, the scope of training is on individual employees (Robert, 2010). It is also job specific and addresses particular performance deficits or problems. Training tends to focus on immediate organizational needs and fairly quick improvement in workers' performance. It strongly influences present performance levels.

A fundamental objective of training is the elimination or improvement of performance problems. To be successful, a training program must have clear stated and realistic goals (David, 2010).These goals will guide the program's content and determine the criteria by which its effectiveness will be judged. For example, management cannot easily realistically expect that one training session will make everyone an accounting expert. Such an expectation guarantees failure because the goal is unattainable. If the goal is to improve specific skills, the training needs to be targeted to those skill areas. In contrast, the company's training goal may be to provide employees with a broader understanding of the organization (Luis, 2010).

\section{Research Objectives}

The research objective is to find out the factors towards training and its effectiveness of training objectives.

The research objectives are:

- To determine the influence of training types on training effectiveness in Kedah state development Corporation Company.

- To determine the influence of training environment on employee's training effectiveness in Kedah state development Corporation Company.

- To determine the influence of work environment on employee's training effectiveness in Kedah state development Corporation Company.

- To determine the affect of employees' personal characteristics (age, gender, marital status, 
education level and length of working in current job) on training effectiveness in Kedah state development Corporation Company.

From the study, the company will know that training of staffs of the company can enhance the sense of belonging and sense of ownership. To company, the more fully on staff training, the more attraction for employees, the more high value-added human resources to invest, thus creating more benefits for enterprises (Ford, 1988). Training not only improves the skills of workers, but also increases awareness of the value of their own employees to have a better understanding of the objectives.

Training also adapt to market changes, competitive advantage. Corporate training is a reserve force to maintain the vitality of business always following the operation. To put it bluntly enterprise competition is the talent competition. Wise entrepreneurs clearly understand that the training is the development cannot be ignored in human investment. Developed countries in promoting technical innovation, not only pay attention to the introduction of mechanical equipment, the upgrading of hardware investment, but pay more attention to improving the quality of the software as the main objective of technical inputs. Facts have proved that talent is the primary resource, with first-class talent, you can develop first-class products, to create first-class performance, and companies can compete in an invincible position in the market.

Therefore the study focus on the evaluation of factors of training effectiveness on human resource practices. An in depth analysis of the possible factors influencing the achievement of training objectives will provide assistance for this study.

\section{Literature Review}

In this part the relevant literature will be reviewed to get a better understanding of the importance of factors affecting employee training and its effectiveness on human resources practice. Firstly, many of these supervisors may feel morally responsible for offering the training program for their employees whether these employees find their jobs satisfying, frustrating, challenging, boring, significant or meaningless becomes a serious concern for these managers.

Secondly, managers are concerned about the factors affecting of employees training has on performance. Many of the organizations heads believe that employee training program can lead to high productivity, low absenteeism and motivation for the job performance.

Examination of theories of employee training and its effectiveness, which aid in determining whether overall employees will feel satisfied or dissatisfied in their training program. It is now important to understand what has led the employee to feel satisfied or dissatisfied in their training program offered by their companies, therefore the causes or sources of training resources will be discussed by each term towards training effectiveness.

\section{Understanding of Training Effectiveness}


In this dynamic and ever changing environment, organizations both public and private must increase the importance on employees' learning and development of skills. This shows that put investment in employee training program can bring employers a favorable return but rarely is the effectiveness of this expenditure assess. Studies suggest that many training and development activities are implemented on blind faith with only the hope that they will yield resist (Arthur, Bennett, Edens \& Bell, 2003) ; According to (Broad and Newstrom, 1992; Robinson and Robinson, 1989). Seldom are training programs rigorously evaluated to determine their effect on the behavior or job performance of participants. One of the more optimistic estimates suggests that no more than 15 percent of learning transfers to the job (Cromwell and Kolb, 2004). Other studies of transfer rates find they typically average only in the 10 to 40 percent range (Baldwin and Ford, 1988; Burke and Hutchins, 2007; Fitzpatrick, 2001; Ford and Kozlowski, 1997). Therefore, it is important to explore methods to encourage transfer of learning in order to achieve greater training impact on human resource practices.

Previous studies (Mayfield, 2011) suggested that training effectiveness is a good predictor of employee training. This association suggests that when employee have been trained in a training program, the training effectiveness is likely to be followed by job behavior (Pelham, 2009). Previous studies also suggest that demographic variables such as age, degree held, and experience were related to training impact in some studies (Devins, Johnson and Sutherland, 2004). The focus of previous work has been on the relationships between training effectiveness and employees' demographic variables.

\section{Trainee Personal Characteristics}

A variety of trainees' personal characteristics have been studied in relation to transfer of learning during the training program. The related personal characteristics that figure out with the age, gender, martial status, and etc. With the trainees' self-confidence and belief in his or her ability to successfully acquire and transfer the target skil (Gist, Stevens \& Bavetta, 1991). For individual training effect, age (Hill, 2002); gender (Chou, 1994; Elizabeth, 2002); marital status (Dewberry, 2001) is also important factors. In the study, these variables as control variables to be more, rather than the independent variables to be studied. The results of these studies is that for the training guide, training, which should be fully taken into account the individual's personality characteristics and psychological interaction between the demographic variables of the training process. This interaction makes the training process more complex. Elizabeth (2002) in the study found, young, highly educated women are more vulnerable than other women training means training to produce a virtuous cycle of career development effect. Trained adult women tend to retire later, suggesting that a more knowledgeable and more wealth to more career women in skills, the ability to stay longer in the professional community. Chou (2001) found that gender and learning style and cognitive style will interact and affect the training methods on the role of training effectiveness. Study also found that gender training methods may also directly regulate the relationship between performance and training. Elizabeth (2002) found 
that some women show a unique "train track" (training track), they will continue to follow the trainer and receive continued.

Trainees with a high degree of education level tend to be more motivated learners and accomplish more (Chiaburu and Marinova, 2005). A direct access has been established between efforts to build the self-confidence of learners and the likelihood of their using skills on the job (Salas and Cannon-Bowers, 2001). This is one of the reasons for investing in good training program and preparing trainees for training. On the other side, understanding the objectives of the training, its relevance to individual and organizational needs and expectations for application can greatly improve learner motivation (Montesino, 2002). Assessing individual needs and providing good environment for training can also have a positive effectiveness on human resource practices among employees in the firm. This is because a better skill among employees is achieved through their personal characteristics. Besides, trainees' ability to improve his or her performance through training

(Salas, Rozel, Mullen \& Driskell , 1999) program itself .According to Sutherland (2009) who found variation on training impact level based on the length of work experience.

\section{Types Of Training}

As in the companies in Malaysia, training for technical and non-technical workers in the organizations under study is mainly job rotation (Hooi, 2010) Though alternatives to training were suggested, the implementation of these programs is still in the infant stage and has yet to achieve desirable results. The types of training and alternatives to training base on the firm needs and also relevant to the employees' job performance.

The local company place little emphasis on training needs analysis and provide training mainly for replacement purposes (Chew, 2005),(Yong, 2003) argues that local firms with less interest in skill enhancement, approach training on a needs basis and limit learning to job specific training. Management in local organizations does not expect employees to commit to lifelong learning especially in new technology and employees do not regard competence enhancement a passport to career advancement. Training and development focus on technical knowledge and skill training with little emphasis on social and intercultural skills and competence development (Rowley and Abdul-Rahman, 2007. The studies show that it is not evidence relationship between the training impact and the types of training. Training type affected firm performance (Devins, Johnson, \& Sutherland, 2004; Kitching \& Blackburn, 2002; Eraut et al., 1998). According to Kitching \& Blackburn, (2002) employees in the smallest organizations are more likely than those employed in the largest organizations to have gained a qualification.

\section{Training Environement}

Training environment that includes: training facilities, site layout, sound lighting, hardware environment, classroom climate, student involvement of the soft environment. Therefore, 
only the training of managers and trainers work together to create a better learning atmosphere and environment. According to (Martin, 2010; Ford, and Weissvein, 1997).Training environment have an effect on training effectiveness on human resource practices among employees .

\section{Work Environment}

Work environment includes such factors as managerial support, peer encouragement, adequate resources, opportunities to apply learned skills, technical support, and consequences for using training on-the-job (Burke and Hutchins, 2008; Colquitt et al., 2000; Kontoghiorghes, 2001; Lim and Morris, 2006; Rouiller and Goldstein, 1993; Tracey et al., 1995). Research has shown that removing barriers to application in the work environment is so important that training opportunities should be turned down by employees if proper follow-up support is not available (Rossett, 1997). Employees have been trained after training program, they should relate to their current job performance and also the behavior of the job. Managers can show support for training in a variety of ways ranging from simply allowing employees to attend the training to participating in the training itself as an instructor (Birdi et al., 1997; Brinkerhoff and Montesino, 1995; Broad and Newstrom, 1992; Burke and Baldwin, 1999). Supervisors signal whether the training is to be used and how quickly changes are expected. A supervisor who does not view the training as useful or relevant can easily undermine application in a variety of direct and covert ways. A supportive organizational climate is also communicated by how the work is designed and skill application rewarded.

Peer support enhances learning transfer through the feedback, encouragement, problem-solving assistance, supplemental information, and coaching provided to trainees (Facteau et al., 1995; Hatala and Fleming, 2007) and may have a stronger influence on trainee transfer than supervisory support (Gilpin-Jackson and Bushe, 2007). In summary, behavioral changes following training will be short-lived without activities to support transfer towards work environment. The most important variable for the purpose of this study is "Training effectiveness" which have an effect on both of organizational needs and individual needs in the company. The independent variables are: 1.types of training (technical or non-technical); 2. Trainees' personal characteristics.(age, gender, martial status, level of education and length of working in current job).3.training environment;4.work environment.

\section{Research Hypotheses}

This study aims to investigate relations between organizational factors which towards training (types of training, training environment and working environment) and individual factors which towards trainees on trainees personal characteristics (age ,gender, martial status, education level and length of working in current job) with training effectiveness. According to our frame work the following hypotheses are formulated.

H1: Types of training between technical training program and non-technical training 
program will affect training effectiveness.

$\mathrm{H} 2$ : Training environment will affect training effectiveness.

H3: Work environment will affect training effectiveness.

H4: Trainees' personal characteristics (age, gender, martial status, education level and length of working in current job) will affect training effectiveness.

\section{Methodology}

A detailed study was undertaken by set of activities. Systems of models, techniques are used to find the results of the research problem. In this study, applied research is used. The researcher tries to solve an ongoing problem within some organizational framework by introducing training models and observing the results of training effectiveness. This research is basic research, as we know, the literature on this study was qualitatively examined and the information was collected by using the questionnaires. Firstly, the research process has been identified and the research problems were formulated. Then, there were also discuss about the instruments to be used and the decisions that should be taken for achieving the purpose of the research were thoroughly analyzed. Later on, the research design was created to answer the research objectives or hypotheses.

In the preliminary stage, the literature of this subject was examined. As a quantitative study, conclusions are based on the questionnaires distributed to respondents. Statistical data used as a medium to obtain needed information. This study aims to determine the relations between independent variable organizational factors towards trainings (types of training, training environment, working environment) and individual factors towards trainees (personal characteristics :age, gender, martial status, education level ,length of working in current job)and dependant variable (training effectiveness on human resource practices). The findings and the conclusion of the study solely depend on the utilization of the statistical data collected.

In order to increase an academic knowledge in conducting a research, the researcher proposed to use questionnaires as a method for collecting data information. The questioners were used for gathering information about the training and its effectiveness (organizational factors toward training program and individual factors toward trainees) on human resource practice. The following section will be an explanation of the instrument applied in this research. The unit of analysis for this study is employees in Kedah State Development Corporation Company.

Before the study was carried out, initial contacts with targeted company (KSDC) were made on April 16, 2011 by formal letter whereby a sample copy of the questionnaire was attached. As a result of these contacts, HR manager of Kedah State Development Corporation agreed to participate and permit other employees to participate in the study .

Population is the target group. The population considered for the study is finite and it includes all employees of KSDC, amounting to 120 people. Sampling unit: The sampling unit is the basic unit containing the elements of the population. It is all members of the population are used as a sample. According to the sample determination table provided by Sekaran (2003), the appropriate sample size for population of 120 is 92(n). 92 sets of 
questionnaires were distributed to KSDC Company. The sample size chosen this study was 92 employees in KSDC Company. It was considered that 92 employees adequate to represent the total population of KSDC. Primary data are the first hand information from the respondents. The researcher considered structured questionnaire while collecting primary data. In this, field study was done, which aims at discovering the relations and interactions among variables.

Secondary data are the published data from KSDC, Books, Online journals, Publications by KSDC, Journals, magazines, websites, etc. The questionnaire is one of the main tools for collecting data from the respondents. The types and designs of questionnaires that are used depend on the studies that have been carried out The questionnaire will be distributed in English and will consist of four sections. First section will ask the demographic information of respondent (gender, age, martial status, education level and etc.). Second section will contain 15 items that measure training effectiveness. In the third section will contain 8 items towards training environment .The last section contains 6 items will ask on work environment. According to Training Effectiveness questionnaires the researcher formulate questionnaire. According to a Likert scale technique which is a psychometric scale commonly used in questionnaires, and is the most widely used scale in survey research. The rating scale from 1 (strongly disagree) to 5 (strongly agree) was used.

\section{Data Analysis}

Various statistical methods will be used to analyze the data that we will collect from the respondents. In this study, the researcher used The Statistical Package for the he latest version (2008) of the Statistical Package for the Social Sciences (SPSS 16.0) will use for the statistical analysis. All the items and variable was coded before entered to the employee. In this study, the responses and information collected from the survey was tested using statistical techniques such as frequency distribution and descriptive statistics, correlation analysis by using the reliability test. Frequency distributions were obtained for all the personal data or classification variables. The frequencies were computed to analyze respondent's profile .Such like frequency analysis use for the respondent's demographic factors of gender, age, and education level, length of working in current job. Besides, Pearson Correlation Analyses were used to examine the relationship between independent variables and the dependent variables. The hypotheses of research will analysis with regression analysis and person correlation analysis with the acceptable Cronbach Alpha values are 0.60 and above (Sekaran, 2003). Therefore, for the items that have low Cronbach Alpha values (less than 0.59) will be eliminated from further analysis process. The statistical tools will be defined as follows:

Percentage analysis: Percentage analysis consists of reducing a series of related amounts to a series of percentages of a given base.

Correlation analysis: The Correlation analysis is performed on log normalized spot expression levels. Spots can then be clustered according to how closely correlated they are. Spots with a high correlation value (i.e. close to 1) show similar expression profiles while 
spots which a high negative correlation value (i.e. close to -1 ) show opposing expression profiles.

Regression analysis: In statistics, regression analysis includes any techniques for modeling and analyzing several variables, when the focus is on the relationship between a dependent variable and one or more independent variables. More specifically, regression analysis helps one understand how the typical value of the dependent variable changes when any one of the independent variables is varied, while the other independent variables are held fixed.

ANOVA : An ANOVA is an analysis of the variation present in an experiment. It is a test of the hypothesis that the variation in an experiment is no greater than that due to normal variation of individuals' characteristics and error in their measurement.

T-test : T-test for comparing the means of two samples (or treatments), even if they have different numbers of replicates. In simple terms, the $t$-test compares the actual difference between two means in relation to the variation in the data (expressed as the standard deviation of the difference between the means).

\section{Research Findings}

Firstly, the main study has an assessment that discusses the respondents' demographic profiles and purification of the measurement variables. Secondly, the reliability tests were conducted to test the consistency of the questionnaires. Thirdly, the hypothesis testing presented through correlation.

\section{Overview of Data Collected}

A total of 92 questionnaires were distributed to employees in KSDC in Kedah State which located in north Malaysia by researcher. All the questionnaires were returned. Hence, 92 questionnaires were used in the statistical analysis, representing a response rate of $100 \%$.

\section{Reliability Test}

Reliability tests were conducted on the independent and dependent variables which are: training effectiveness, training environment, and work environment. The Cronbach's alpha values of the study variables are shown in table. As revealed, the reliability coefficient of the study variables exceeded the minimum acceptable level of 0.60 (Nunnally, 1978). As a result, Cronbach's alpha for the training impact variable is $(0.805)$; for training environment variable (0.697); and finally, for work environment (0.700).

Table: 1 Reliability Coefficient of the Study Variables

\begin{tabular}{|l|l|l|l|}
\hline Variables & Total Items & $\begin{array}{l}\text { No. of Items } \\
\text { Deleted }\end{array}$ & $\begin{array}{l}\text { Alpha } \\
\text { Coefficient }\end{array}$ \\
\hline Training Effectiveness & 15 & None & 0.805 \\
\hline Training Environment & 8 & None & 0.697 \\
\hline Work Environment & 6 & None & 0.700 \\
\hline
\end{tabular}




\section{Macrothink

\section{The Results of Hypotheses Testing}

\section{Correlation Analysis}

Correlation test used for inferential statistics. The Pearson correlation will be used to measure the significance of linear bivariate between the independent and dependent variables thereby achieving the objective of this study (Sekaran, 2003). Variable association refers to a wide variety of coefficients which measure the strength of a relationship among variables in the model. Furthermore, correlation is a bivariate measure of association (strength) of the relationship between two variables. It varies from 0 (random relationship) to 1 (perfect linear relationship) or -1 (perfect negative linear relationship). It is usually reported in terms of its square $\left(\mathrm{r}^{2}\right)$, interpreted as percent of variance explained (Hair, Black, Babin, Anderson \& Tatham, 2006). Table 4.7 below shows that organization variable was partially significantly correlated in with training effectiveness. Types of training was not significantly correlated with training effectiveness (-0.087), training environment was more significantly correlated with training effectiveness (0.495), and work environment was correlate variable with training effectiveness with high value equal to (0.367).

Table: 2 Correlations between Variables

\begin{tabular}{|c|c|c|c|c|c|}
\hline & & $\begin{array}{l}\text { types } \\
\text { of } \\
\text { training }\end{array}$ & TI & TE & WE \\
\hline \multirow{3}{*}{$\begin{array}{l}\text { types of } \\
\text { training }\end{array}$} & Pearson & 1 & -.087 & -.034 & .027 \\
\hline & Sig. (2-tailed) & & 410 & .750 & .799 \\
\hline & $\mathrm{N}$ & 92 & 92 & 92 & 92 \\
\hline \multirow[t]{4}{*}{ TEF } & Pearson & 087 & 1 & $.495(* *$ & $.367(* *$ \\
\hline & Correlation & $-.08 /$ & 1 & ) & ) \\
\hline & Sig. (2-tailed) & .410 & & .000 & .000 \\
\hline & $\mathrm{N}$ & 92 & 92 & 92 & 92 \\
\hline \multirow[t]{4}{*}{$\mathrm{TE}$} & Pearson & 034 & $.495(* *$ & 1 & $.338(* *$ \\
\hline & Correlation & & & & ) \\
\hline & Sig. (2-tailed) & .750 & .000 & & .001 \\
\hline & $\mathrm{N}$ & 92 & 92 & 92 & 92 \\
\hline \multirow[t]{4}{*}{ WE } & Pearson & .027 & $.367(* *$ & $.338(* *$ & 1 \\
\hline & Correlation & & & ) & \\
\hline & Sig. (2-tailed) & .799 & .000 & .001 & \\
\hline & $\mathrm{N}$ & 92 & 92 & 92 & 92 \\
\hline
\end{tabular}

Correlation is significant at the 0.01 level (2-tailed). 
Regression Results

The first hypotheses of this study proposed that training types would affect training effectiveness in Kedah state development corporation. Hence, to determine to what extend the training types influence the employees' training effectiveness on human resource practices regression test was conducted. As shown in table 4.8, the results of regression test the training types as the independent variable against training effectiveness as the dependent variable. The results of regression analysis indicated an insignificant $p$ value $p>0.05(0.410)$. Therefore it can be concluded that training types does not affect the training effectiveness.

Table: 3 Regression between Types of Training and Training Effectiveness

\begin{tabular}{|c|c|c|c|c|c|c|c|}
\hline \multirow[t]{2}{*}{ Model } & \multirow[b]{2}{*}{$\mathrm{R}$} & \multirow[b]{2}{*}{$\begin{array}{l}\mathrm{R} \\
\text { Square }\end{array}$} & \multicolumn{2}{|c|}{$\begin{array}{l}\text { Unstandardized } \\
\text { Coefficients }\end{array}$} & \multirow{2}{*}{$\begin{array}{l}\text { Standardiz } \\
\text { ed } \\
\text { Coefficient } \\
\text { s } \\
\text { Beta }\end{array}$} & \multirow{2}{*}{\begin{tabular}{|l}
$\mathrm{t}$ \\
$\begin{array}{l}\text { Low } \\
\text { er } \\
\text { Bou } \\
\text { nd }\end{array}$ \\
\end{tabular}} & \multirow{2}{*}{\begin{tabular}{|l} 
Sig. \\
Up \\
per \\
Bo \\
und \\
\end{tabular}} \\
\hline & & & B & $\begin{array}{l}\text { Std. } \\
\text { Error }\end{array}$ & & & \\
\hline $\begin{array}{l}1 \text { (Constant } \\
\text { ) } \\
\text { Types of } \\
\text { Training }\end{array}$ & $\begin{array}{l}.08 \\
7\end{array}$ & .008 & $\begin{array}{l}3.708 \\
-0.07 \\
2 \\
\end{array}$ & $\begin{array}{l}0.151 \\
0.087\end{array}$ & -0.087 & \begin{tabular}{|l|}
24.4 \\
84 \\
0.82 \\
8 \\
\end{tabular} & $\begin{array}{l}0.0 \\
00 \\
.41 \\
0 \\
\end{array}$ \\
\hline
\end{tabular}

Dependent Variable: TEF

The second hypotheses of this study proposed that training environment would affect training effectiveness in Kedah state development corporation. Hence, to determine to what extend the training environment influence the employees' training effectiveness on human resource practices regression test was conducted. As shown in table 4.9, the results of regression test the training environment as the independent variable against training effectiveness as the dependent variable. The results of regression analysis indicated a significant $\mathrm{p}$ value $\mathrm{p}<0.05(0.001)$. Therefore it can be concluded that training environment influences the training effectiveness and significantly contribute to the $\mathrm{R}$ square value. The results of regression analysis indicated that training environment explained about $25 \%\left(\mathrm{R}^{2}=\right.$ 0.245) of the variance in training effectiveness. 
Table: 4 Regressions between Training Environment and Training Effectiveness

\begin{tabular}{|c|c|c|c|c|c|c|c|}
\hline \multirow[t]{2}{*}{ Model } & \multirow[b]{2}{*}{$\mathrm{R}$} & \multirow[b]{2}{*}{$\begin{array}{l}\mathrm{R} \\
\text { Square }\end{array}$} & \multicolumn{2}{|c|}{$\begin{array}{l}\text { Unstandardized } \\
\text { Coefficients }\end{array}$} & \multirow[t]{2}{*}{$\begin{array}{l}\text { Standardiz } \\
\text { ed } \\
\text { Coefficient } \\
\text { s }\end{array}$} & \multirow{2}{*}{$\begin{array}{l}\text { t } \\
\text { Low } \\
\text { er } \\
\text { Bou } \\
\text { nd }\end{array}$} & \multirow{2}{*}{$\begin{array}{l}\text { Sig. } \\
\text { Up } \\
\text { per } \\
\text { Bo } \\
\text { und }\end{array}$} \\
\hline & & & B & $\begin{array}{l}\text { Std. } \\
\text { Error }\end{array}$ & & & \\
\hline $\begin{array}{l}1 \text { (Constant) } \\
\text { Training } \\
\text { environme } \\
\text { nt }\end{array}$ & $\begin{array}{l}.49 \\
5\end{array}$ & .245 & $\begin{array}{l}1.874 \\
.481\end{array}$ & $\begin{array}{l}.319 \\
.089\end{array}$ & .495 & $\begin{array}{l}.879 \\
.406\end{array}$ & $\begin{array}{l}.00 \\
0 \\
.00 \\
0\end{array}$ \\
\hline
\end{tabular}

Dependent Variable: TEF

The third hypotheses of this study proposed that work environment would affect training effectiveness on human resource practices in Kedah state development corporation. Hence, to determine to what extend the work environment influence the employees' training effectiveness on human resource practices regression test was conducted. As shown in table 4.10, the results of regression test the work environment as the independent variable against training effectiveness as the dependent variable. The results of regression analysis indicated a significant $\mathrm{p}$ value $\mathrm{p}<0.05$ (0.001). Therefore, it can be concluded that work environment affects the training effectiveness and significantly contribute to the $\mathrm{R}$ square value. The results of regression analysis indicated that work environment contributed about $14 \%\left(\mathrm{R}^{2}\right.$ $=0.135)$ to the variance in training effectiveness.

Table: 5 Regression between work environment and Training Effectiveness

\begin{tabular}{|c|c|c|c|c|c|c|c|}
\hline \multirow[t]{2}{*}{ Model } & \multirow[b]{2}{*}{$R$} & \multirow[b]{2}{*}{$\begin{array}{l}\mathrm{R} \\
\text { Square }\end{array}$} & \multicolumn{2}{|c|}{$\begin{array}{l}\text { Unstandardized } \\
\text { Coefficients }\end{array}$} & \multirow{2}{*}{$\begin{array}{l}\text { Standardi } \\
\text { zed } \\
\text { Coefficie } \\
\text { nts } \\
\\
\\
\text { Beta } \\
\end{array}$} & \multirow[b]{2}{*}{$\begin{array}{l}\mathrm{t} \\
\text { Lower } \\
\text { Bound }\end{array}$} & \multirow{2}{*}{$\begin{array}{l}\text { Sig. } \\
\text { Up } \\
\text { per } \\
\text { Bo } \\
\text { und }\end{array}$} \\
\hline & & & B & $\begin{array}{l}\text { Std. } \\
\text { Error }\end{array}$ & & & \\
\hline $\begin{array}{l}1 \text { (Constant) } \\
\\
\text { Work } \\
\text { environment }\end{array}$ & $\begin{array}{l}.36 \\
7\end{array}$ & .135 & $\begin{array}{l}2.40 \\
5 \\
.324\end{array}$ & $\begin{array}{l}.318 \\
.086\end{array}$ & .367 & $\begin{array}{l}.566 \\
.744\end{array}$ & $\begin{array}{l}.00 \\
0 \\
.00 \\
0\end{array}$ \\
\hline
\end{tabular}

Dependent Variable: TEF 


\section{Analysis of Differences}

T-test is used to find the differences between training effectiveness with gender. Likewise t-test is used to find the differences between training effectiveness with marital status. Otherwise, the ANOVA is used to find differences between training effectiveness with age, educational level, and length of work experience. Independent sample t-test is applied in many researches concerns the means and standard deviations of two groups on the variable and examines whether the numerical difference in the means is significantly different from 0 (zero) as postulated in null hypotheses (Sekaran, 2003).

\section{Gender and Training Effectiveness}

From the table it is observed that the results of testing the differences between male and female who were participants did not have different scores of training effectiveness at significant level 0.05 levels $(t=0.435$, and $p=.435$ which is $p>0.05)$. The results of data analysis are shown in table 6 below.

\section{T-Test Result between Male and Female}

Table: $6 \mathrm{~T}$ test

\begin{tabular}{|c|l|l|l|}
\hline No & Male & Female & Sig \\
\hline \multirow{2}{*}{$\begin{array}{c}\text { Mean } \\
\text { SD }\end{array}$} & 3.545 & 3.611 & .435 \\
& .475 & .333 & \\
\hline
\end{tabular}

\section{Age and Training Effectiveness}

In order to find the differences between age and training effectiveness, it is observed from ANOVA test results that there are no differences among the respondents' age regarding the training effectiveness levels. With $(\mathrm{F}=0.597, \mathrm{p}>0.05)$, there is no differences between three ages groups on training effectiveness. This is shown in Table 7

Table: 7 One Way ANOVA of Age Groups on Training Effectiveness Variable

\begin{tabular}{|l|l|l|l|}
\hline Age & Mean & F & Sig \\
\hline Under 25 Years & 3.651 & .695 & .597 \\
\cline { 1 - 2 } 25-35 years & 3.626 & & \\
\cline { 1 - 2 } 36-45 years & 3.606 & & \\
\cline { 1 - 2 } $46-55$ & 3.460 & & \\
\cline { 1 - 2 } $\begin{array}{l}\text { More than 55 } \\
\text { years }\end{array}$ & 3.622 & \\
\cline { 1 - 2 } Total & 3.587 & & \\
\hline
\end{tabular}




\section{Marital Status and Training Effectiveness}

From the table it is observed that the results of testing the differences between single respondents and married respondents who were participants did not have different scores of training effectiveness at significant level 0.05 levels $(\mathrm{t}=0.528, \mathrm{p}>0.05)$. Based on means, the male participants were better than female participants in received training. The results of data analysis are shown in table: 8 below.

Table: 8 T-Test Result between Single and Married Respondents

\begin{tabular}{|c|l|l|l|}
\hline No & Single & Married & Sig \\
\hline \multirow{2}{*}{$\begin{array}{c}\text { Mean } \\
\text { SD }\end{array}$} & 3.627 & 3.570 & .528 \\
& .420 & .528 & \\
\hline
\end{tabular}

\section{Educational Level with Training Effectiveness}

In order to find the differences between respondents based on their educational level and training effectiveness, it is observed from ANOVA test results that there are no differences among the respondents' educational level regarding the training effectiveness levels. With $(\mathrm{F}=1.491, \mathrm{p}=.201 ;>0.05)$. This is shown in table: 9 .

Table: 9 One Way ANOVA of Educational Level and Training Effectiveness Variable

\begin{tabular}{|l|l|l|l|}
\hline Education Level & Mean & F & Sig \\
\cline { 1 - 2 } SPM below & 3.497 & & .491 \\
\cline { 1 - 2 } SPTM/diploma & 3.658 & & \\
\cline { 1 - 2 } Bachelor & 3.478 & & \\
\cline { 1 - 2 } Master & 3.688 & \\
\cline { 1 - 2 } Phd & 3.866 & \\
\cline { 1 - 2 } Professional & 3.933 & \\
\cline { 1 - 2 } Total & 3.587 & \\
\hline
\end{tabular}

\section{Work Experience and Training Effectiveness}

In order to find the differences between respondents based on their length of work experience and training impact, it is observed from ANOVA test results that there are a significant differences among the respondents' regarding the training effectiveness levels based on their work experience. With $(\mathrm{F}=5.030, \mathrm{p}=.003 ;>0.05)$, this is shown in table: 10 Results showed the less experienced participants have higher training effectiveness (mean = 3.819). 
Table: 10 One Way ANOVA of Work Experience and Training Effectiveness Variable

\begin{tabular}{|l|l|l|l|}
\hline Work Experience & Mean & F & Sig \\
\hline Below 5 years & 3.819 & 5.030 & .003 \\
\cline { 1 - 1 } 6-10 years & 3.595 & & \\
\cline { 1 - 2 } 11-15 years & 3.526 & & \\
\cline { 1 - 2 } Above 16 years & 3.425 & & \\
\cline { 1 - 2 } Total & 3.587 & & \\
\hline
\end{tabular}

\section{Conclusion}

The result of the final relationship variables and the testing of the influence of the variables are detailed to figure the relationship and degree of influence among predictors for the training effectiveness as dependent variable.(Table:11 below)

Table: 11 Relationship variables

\begin{tabular}{|l|l|}
\hline Hypotheses & Results \\
\hline $\begin{array}{l}\text { Types of training between technical training program and } \\
\text { non-technical training program will affect training effectiveness. } \\
\text { Training environment will affect training effectiveness. }\end{array}$ & Rejected \\
Work environment will affect training effectiveness. & Accepted \\
$\begin{array}{l}\text { Trainees' personal characteristics (age, gender, marital status, } \\
\text { education level and length of working in current job) will affect } \\
\text { training effectiveness. }\end{array}$ & $\begin{array}{l}\text { Accepted } \\
\text { Accepted }\end{array}$ \\
\hline
\end{tabular}

\section{Discussions and Conclusions}

The purpose of this study was to examine whether that organizational factors such as (types of training, training environment, work environment influence training effectiveness among employees in their workplace. The results supported that some factors such as training environment and work environment significant correlation with training effectiveness in organization. Other purposes of this study were to examine whether there were a significant differences between males and females, respondents age, level of education, marital status, and length of work experience of respondents on the training effectiveness. The problem and the gap in the research and literature arise from the fact that organizational and individuals' factors have not been identified widely.

Various methods of analysis were used in measurement. First are the demographic factors or personal information about the respondents which need to be considered in the study as it could describe the respondents' characteristics and their background. Different personal 
backgrounds would mean different personality and different levels of job performance among the respondents.

The demographic part was dealt based on the descriptive analysis. The aims of the analysis are to see the total percentage of those respondents based on the demographic factors which as mentioned earlier include: gender, age, marital status, educational level and work experience. Gender of respondents shows that male respondents are (43) in number making $(37 \%)$ while female respondents makes (58) and is represented by $(63 \%)$ this make a total of $100 \%$ of the gender of the respondents. The age of the respondents shows that the age range under 25 years had 13 respondents $(14.1 \%)$; 25-35 years had 25 respondents $(27.2 \%)$ and 36-45 years had 31and represented (33.7\%), 46-55 years had 20 and represented (21.7\%), and more than 56 years had 3 respondents (3.3\%) which the total gives 92 which is $100 \%$. The marital status had singles having (27) respondents (29.3\%) and married respondents had 65 with $(71.7 \%)$ with total $100 \%$. Most of respondents have SPTM/DIPLOMA education level which is $(26.15 \%)$ and only 2 of them were professional. Finally, work experience shows that respondents have different length of work experience and most of respondents having more than 11 years work experience.

Training for organizations seem to be imperative process to improve the equality and products of the firm. Thus, this study attempt to determine factors related to firm performance. Overall, the results from this study yielded somewhat mixed results on the effects of organization factors on firm training effectiveness. Furthermore, the outcomes from analyzing the demographics variables did not differentiate between male and female as well as between respondent's ages, educational level, marital status on the level of training effectiveness. Only one of individual variables has been found to affect training effectiveness which is length of work experience. The specific research hypotheses addressed were:

H1: Types of training between technical training program and non-technical training program will affect training effectiveness.

H2: Training environment will affect training effectiveness .

H3: Work environment will affect training effectiveness.

H4: Trainees' personal characteristics (age, gender, marital status, education level and length of working in current job) will affect training effectiveness.

\section{H1: Types of training between technical training program and non-technical training program will affect training effectiveness.}

Regression analysis was conducted to asses if the type of training affects training effectiveness among this study sample. The results from this study indicated insignificant $(0.410 ; p>0.05)$ correlation between these variables which somewhat inconsistent with previous studies who found that training types affected firm performance (Devins, Johnson, \& Sutherland, 2004; Kitching \& Blackburn, 2002; Eraut et al., 1998). One possible justification for the inconsistent result of this hypothesis due to largest number of employees in the organization. According to Kitching \& Blackburn, (2002) employees in the smallest organizations are more likely than those employed in the largest organizations to have 
gained a qualification. Therefore, types of training do not influence the training effectiveness in this study.

\section{H2: Training environment will affect training effectiveness.}

Regression analysis was conducted to asses if the training environment affects training effectiveness among employees. The result showed that training environment influencing the probability positive outcome for employees. The result was consistent with previous studies who found that training has positive outcome in firm performance (Martin, 2010; Ford \& Weissvein, 1997).

\section{H3: Work environment will affect training effectiveness.}

Regression analysis was conducted to asses if the work environment affects training effectiveness among employees performance. Workplace environment has found to be factor necessary for enhancing individual performance. The result of this study hypothesis was statistically significant $(0.000 ; \mathrm{p}<0.05)$ which was consistent with previous studies who found work environment lead to positive firm performance (Kontoghiorghes, 2001; Lim \& Morris, 2006). A various researchers (Rouiller \& Goldstein, 1993; Tracey et al., 1995; Burke \& Hutchins, 2008; Colquitt et al., 2000) have agreed the importnce of workplace environment factors such as managerial support, peer encouragement, adequate resources, opportunities to apply learned skills, technical support, and consequences for using training on-the-job.

H4: Trainees' personal characteristics (age, gender, marital status, education level and length of working in current job) will affect training effectiveness.

There is a strong call from previous studies regarding to test individual variables on workplace setting. Sample t-test and ANOVA was conducted to assess if differences exists between gender, age, marital status, educational level, and work experience among respondents on training effectiveness. The findings from this study indicated some notable differences associated with some employee characteristics. For example only length of work experience has been found to be factor influenced training effectiveness $(0.003 ;<0.05)$. Otherwise, none of remains factors (gender, age, marital status, and educational level did not find to influence training effectiveness. The results somehow was consistent with Sutherland (2009) who found variation on training effectiveness level based on the length of work experience, in other hand the results was inconsistent with Sutherland (2009) who found a variation on training effectiveness based on gender and age variables.

\section{Implication of the Study}

The results of this study provide major contribution to knowledge. First, it provides clear understanding of organization and individual variables on training effectiveness in organization. There has been very little empirical work to verify or refute them. This study has described the key components of organizations and their effects. From the findings it has been found that a positive relationship between training environment and work environment with the training effectiveness. Therefore, these findings indicated that it is important for the management to consider the factors and characteristics of individuals before setting up the goals. Management team should emphasize training opportunities as they may relate to increase job performance with enough training. As a result if these factors 


\section{Al Macrothink \\ International Journal of Human Resource Studies \\ ISSN 2162-3058 \\ 2011, Vol. 1, No. 2}

are considered, an organization will increase its chances of success.

\section{Recommendation of Future Research}

According to limitation of this study, the sample may not be representative of the population because the sample drawn from one organization in Kedah State in North Malaysia, and did not involve other locations or different organizations in Malaysia. In addition, this research chooses only on public firm, therefore, it would be beneficial for future research to consider the suggestion that weather in public or in private organizations expand the study to enhance the consistency of the results. In addition, further studies will be conducted in order to determine the validity of the model in other organization as well as taking into consideration other variables to measure training among the companies so that this will increase the accuracy of understanding the drivers that could impact training .

\section{Conclusion}

The objectives in this study have been achieved whereby the results had shown that training environment, work environment and employees' characteristics are related to training effectiveness in Kedah State Development Corporation Company. Training environment is found to be the strongest driver of training effectiveness in Kedah State Development Company .Therefore; it should channel more time and resources in this area as it brings a great effectiveness of Kedah State Development Corporation Company. Researchers suggest that KSDC Company should take a look at the inordinate amounts of time and money spent on program or curriculum design and redesign. If something is not working in a company, training specialists are brought in to improve or upgrade the courses. New programs are sought, written and bought in hopes that this will improve the quality of training for the employees. Also take a look at the tests used after a training program, if any are used at all. The implication is that passing these tests indicates the employees possess a certain level of intellectual competency and should be able to implement what they were taught back on the job. Besides, trainers are often rewarded and evaluated based on the number of employees who like the class. For company needs, not necessarily the people. And, when these courses are taught, there is very rarely any noticeable behavioral change or improvement in the workplace.

With the results of this study also given an avenue for the organization under study to have a working material and an update on their employees which all enable them put the results into practice. The results will also be applicable in other related organizations in the country as they have similar characteristics. Conclusively, the result has brought up to organization factors under study which will be beneficial to their organization performance. Finally, this research is significant as a theoretical contribution in exploring the training impact that the organization and individual variables are having an effect on the organizations training effectiveness. 


\section{References:}

Abderrahman Hassi, Giovanna Storti, (2011) "Organizational training across cultures: variations in practices and attitudes", Journal of European Industrial Training, Vol. 35 Iss: 1, pp. $45-70$

Aaron W. Hughey, Kenneth J. Mussnug, (1997) "Designing effective employee training programmes", Training for Quality, Vol. 5 Iss: 2, pp.52 - 57

Alfred Pelham, (2009) "The impact of industry and training influences on salesforce consulting time and consulting effectiveness", Journal of Business \& Industrial Marketing, Vol. 24 Iss: 8, pp.575 - 584

Arthur, W., Bennett, W., Edens, P.S., Bell, S.T. (2003), "Effectiveness of training in organizations: a meta-analysis of design and evaluation features", Journal of Applied Psychology, Vol. 88 No.2, pp.234-45.

Burke, L.A., Baldwin, T.T. (1999), "Workforce training transfer: a study of the effect of relapse prevention training and transfer", Human Resource Management, Vol. 38 No.3, pp.227-42.

Baldwin, T.T., Ford, J.K. (1988), "Transfer of training: a review and directions for future research", Personnel Psychology, Vol. 41 No.1, pp.63-105.

Burke, L.A., Hutchins, H.M. (2008), "A study of best practices in training transfer and proposed model of transfer", Human Resource Development Quarterly, Vol. 19 No.2, pp.107-28.

Birdi, K., Allan, C., Warr, P. (1997), "Correlates of perceived outcomes of four types of employee development activity", Journal of Applied Psychology, Vol. 82 No.6, pp.845-57.

Colquitt, J.A., LePine, J.A., Noe, R.A. (2000), "Toward an integrative theory of training motivation: a meta-analytic path analysis of 20 years of research", Journal of Applied Psychology, Vol. 85 No.5, pp.678-707.

Cromwell, S.E., Kolb, J.A. (2004), "An examination of work-environment support factors affecting transfer of supervisory skills training to the workplace", Human Resource Development Quarterly, Vol. 15 No.4, pp.449-71.

Chew, Y.T. (2005), "The changing HRM practices of Japanese firms and the impacts on compensation practices of Japanese affiliates in Malaysia", Forum of International Development, Vol. 28 No.1, pp.55-80.

Chiaburu, D.S., Marinova, S.V. (2005), "What predicts skill transfer? An exploratory study of goal orientation, training self-efficacy, and organizational supports", International Journal of Training and Development, Vol. 9 No.2, pp.110-23.

David Devins, Steve Johnson, John Sutherland, (2004) "Employer characteristics and employee training outcomes in UK SMEs: a multivariate analysis", Journal of Small Business and Enterprise Development, Vol. 11 Iss: 4, pp.449 - 457

Devins, D., Johnson, S., \& Sutherland, J. (2004). Employer characteristics and employee training outcomes in UK SMEs: a multivariate analysis, Journal of Small Business and Enterprise Development, 11(4), 449-457. 
Eraut, M., Alderton, J., Cole, G., Senker, P. (1998), Development of Knowledge and Skills in Employment, University of Sussex Institute of Education, Brighton, Research Report No. 5, .

Facteau, J.D., Dobbins, G.H., Russell, J.E.A., Ladd, R.T., Kudisch, J.D. (1995), "The influence of general perceptions of the training environment on pre-training motivation and perceived training transfer", Journal of Management, Vol. 21 No.1, pp. $1-25$

Ford, J.K., Weissbein, D.A. (1997), "Transfer of training: an updated review and analysis", Performance Improvement Quarterly, Vol. 10 No.2, pp.22-41.

Gist, M.E., Stevens, C.K., Bavetta, A.G. (1991), "Effects of self-efficacy and post-training intervention on the acquisition and maintenance of complete interpersonal skills", Personnel Psychology, Vol. 44 No.4, pp.837-61

Gilpin-Jackson, Y., Bushe, G.R. (2007), "Leadership development training transfer: a case study of post-training determinants", Journal of Management Development, Vol. 26 No.10, pp.980-1004.

Hair, J. F., Black, W. C., Babin, B. J., Anderson, R. e, \& Tatham, R. L. (2006). Multivariate Data Analysis, $6^{\text {th }}$ ed. New Jersey, Prentic Hall.

Harry J. Martin, (2010) "Improving training impact through effective follow-up: techniques and their application", Journal of Management Development, Vol. 29 Iss: 6, pp.520 534

Heli Aramo-Immonen, Kaj U. Koskinen, Pasi L. Porkka, (2011) "The significance of formal training in project-based companies", International Journal of Managing Projects in Business, Vol. 4 Iss: 2, pp.257-273

Hawley, J.D., Barnard, J.K. (2005), "Work environment characteristics and implications for training transfer: a case study of the nuclear power industry", Human Resource Development International, Vol. 8 No.1, pp.65-80.

John Sutherland, (2009) "Skills and training in Great Britain: further evidence", Education + Training, Vol. 51 Iss: 7 , pp. $541-554$

Kitching, J., Blackburn, R. (2002), The Nature of Training and Motivation to Train in Small Firms., DfES, London, Research Report RR330.

Kontoghiorghes, C. (2001), "Factors affecting training effectiveness in the context of the introduction of new technology - a US case study", International Journal of Training and Development, Vol. 5 No.4, pp.248-60.

Lim, D.H., Morris, M.L. (2006), "Influence of trainee characteristics, instructional satisfaction, and organizational climate on perceived learning and training transfer", Human Resource Development Quarterly, Vol. 17 No.1, pp.85-115.

Lai Wan Hooi, (2010) "Technical training in the MNCs in Malaysia: a case study analysis of the petrochemical industry", Journal of European Industrial Training, Vol. 34 Iss: 4, pp. $317-343$

Milton Mayfield, (2011) "Creating training and development programs: using the ADDIE method", Development and Learning in Organizations, Vol. 25 Iss: 3, pp.19-22 
Montesino, M.U. (2002), "Strategic alignment of training, transfer-enhancing behaviors, and training usage: a post-training study", Human Resource Development Quarterly, Vol. 13 No.1, pp.89-108.

Martin, H. (2010). Improving Training Impact through Effective follow-up: Techniques and their Application, Journal of Management Development, 29 (61), 520-534.

Nunnally, J. C. (1978). Psychometric Theory. New York, NY: McGraw Hill.

Rouiller, J.Z., Goldstein, I.L. (1993), "The relationship between organizational transfer climate and positive transfer of training", Human Resource Development Quarterly, Vol. 4 No.4, pp.377-90.

Rossett, A. (1997), "It was a great class, but ...", Training and Development, Vol. 51 No.7, pp.18-24.

Rowley, C., Bhopal, M. (2006), "The ethnic factor in state-labour relations", Capital and Class, Vol. 88 pp.87-116

Salas, E., Rozell, D., Mullen, B., Driskell, J.E. (1999), "The effect of team building on performance: an integration", Small Group Research, Vol. 30 No.3, pp.309-29.

Salas, E., Cannon-Bowers, J.A. (2001), "The science of training: a decade of progress", Annual Review of Psychology, Vol. 52 pp.471-99.

Sekaran, U. (2003). Research method for business: A skill-building approach (4th ed). New Youk: John Wiley \& sons Inc.

Sutherland, J. (2009). Skills and Training in Great Britain: further evidence, Journal of Education and Training, 51 (7), 541-554.

Tracey, J.B., Tannenbaum, S.I., Kavanagh, M.J. (1995), "Applying trained skills on the job: the importance of the work environment", Journal of Applied Psychology, Vol. 80 No.2, pp.239-52.

Yong, K.B. (2003), "Human resource management", in Malaysian Institute of Management (Eds),Management in Malaysia, Percetakan Printpack Sdn. Bhd, Shah Alam, pp.230-50. 